\title{
Perancangan Video Company Profile Instansi Badan Pengelolaan Pajak Dan Retribusi Daerah Kota Batam
}

\author{
Evita $^{1}$, Dwi Ely Kurniawan. S.Pd., M.Kom. ${ }^{2}$ \\ Mahasiswa Politeknik Negeri Batam ${ }^{1}$, Dosen Politeknik Negeri Batam ${ }^{2}$ \\ Teknik Multimedia Jaringan ${ }^{1}$, Politeknik Negeri Batam ${ }^{2}$ \\ elvifebianti@gmail.com ${ }^{1}$, dwialikhs@gmail.com ${ }^{2}$
}

\begin{tabular}{l} 
Article Info \\
\hline Article history: \\
Received Jun $12^{\text {th }}, 2021$ \\
Revised Jun $20^{\text {th }}, 2021$ \\
Accepted Jul $26^{\text {th }}, 2021$ \\
\hline
\end{tabular}

Keyword:

BPPRD Kota Batam, Company Profile, perancangan, video

\begin{abstract}
Badan Pengelolaan Pajak dan Retribusi Daerah (BP2RD) of Batam City is a government agency engaged in tax and retribution services. To maximize local tax and retribution services to the community, BP2RD Batam City requires information media facilities that can introduce agency assets as well as transparency of taxes and levies to leaders, other agencies, and taxpayers. The media will be made in the form of a video company profile. The method of data collection was carried out by means of field observations, interviews, and literature studies. based on the results of the test analysis by obtaining an average percentage value of $92.5 \%$, where the proportion value falls into the good response scale category. Videos will be created using Adobe Premiere Pro cc 2015 software, Adobe After Effects CS6, and Filmora. After that, quantitative research will be carried out by interviewing respondents and it will be measured with an instrument in the form of a Guttman scale.
\end{abstract}

\section{Pendahuluan}

Majunya teknologi dan informasi di era globalisasi di zaman sekarang mengalami kemajuan yang sangat pesat dalam segala bidang, termasuk dalam bidang pemerintahan. Pemerintah memanfaatkan kemajuan ini dalam mencapai visi dan misi dalam melayani kebutuhan informasi masyarakat. Salah satu Instansi Pemerintah di Kota Batam yang memanfaatkan perkembangan teknologi dan informasi tersebut adalah BP2RD. BP2RD bergerak dibidang jasa pelayanan pajak dan retribusi. BP2RD berlokasi di Telrk Tering Kecamatan Batam Kota, Kota Batam, Kepri, Gedung Bersama Pemko Batam.

Bagi masyarakat pembayaran pajak dan retribusi sangat penting untuk pembangunan di Batam. BP2RD Batam memerlukan sarana media informasi yang dapat dipergunakan untuk memperkenalkan aset instansi serta transparansi pajak dan retribusi kepada pimpinan, instansi lain, dan wajib pajak. Media yang dimiliki oleh BP2RD Batam masih berupa media cetak, yakni menggunakan buku sebagai media promosi serta publikasi. Buku tersebut tidak tersebar luas secara umum, hal ini membuat BP2RD tidak bisa dijangkau masyarakat luas dan transparan dalam pelayanannya. Oleh karena itu, BP2RD membutuhkan media informasi digital yang berbentuk video, digunakan membantu penyampaian profile instansi dengan modern serta dapat disebarluaskan secara umum.

Referensi dalam pembuatan Tugas Akhir ini adalah penelitian dari (Kausar et al., 2015), dalam penelitiannya telah berhasil menciptakan video company profile dengan penyampaian informasi akan cepat dipahami masyarakat. Sedangkan penelitian dari (Kusuma, 2013) telah berhasil membuat company profile berbasis video dengan resolusi 1920x1080.

Menurut (Maimunah et al., 2012) dalam jurnalnya company profile adalah sebuah aset suatu lembaga atau perusahaan yang dapat digunakan untuk meningkatkan suatu image atau citra dari perusahaan untuk menjalin kerja sama dengan relasi perusahaan, lembaga dan instansi yang terkait lainya. Menurut (Sunarya et al., 2012) company profile adalah sebuah aset suatu lembaga atau perusahaan yang biasa digunakan sebagai tanda pengenal dalam melakukan komunikasi baik dan kerjasama dalam lingkup internal perusahaan maupun dengan kolega, mitra usaha ataupun pihak-pihak terkait lainnya di luar lingkungan perusahaan tersebut.

Menurut (Kriyantono et al., 2008) fungsi company profile adalah representasi perusahaan, merupakan gambaran tentang perusahaan. Bisa digunakan untuk melengkapi komunikasi lisan demi terciptanya mutual understanding. Menghemat waktu transaksi, pihak pihak lain yang berkaitan dengan bisnis perusahaan tidak perlu menanyakan secara detail tentang perusahaan, 
produk, pasar, visi, misi, posisi keuangan. Hal itu dapat dipelajari melalui company profile. Menurut pendapat di atas, video company profile adalah salah satu media informasi untuk memasarkan atau mengenalkan Instansi atau perusahaan pada konsumen atau klien Instansi atau perusahaan.

Dari uraian permasalahan yang didapat penulis mendapatkan ide untuk membuat video company profile mengenai BP2RD. Selain itu video tersebut bisa dipergunakan untuk hal berkepentingan serta menyorong proses transparasinya dan akuntabilitasnya pengelolaan pendapatan kota Batam secara efektif dan efisien. Pada tahap pengeditan, penulis akan memakai aplikasi Adobe Premiere Pro cc 2015, Adobe After Effect CS6, dan Filmora.

\section{Metode Penelitian}

\section{A. Metode Pengumpulan Data}

1) Metode Pengumpulan Data: Mendatangi secara langsung BP2RD Kota Batam, untuk meminta informasi tentang BP2RD Kota Batam serta meminta izin untuk melakukan pengambilan gambar di sekitar instansi.

2) Wawancara: Pengumpulan data akan dilakukan dengan cara mewawancarai pihak instansi dan akan disepakati bahwa hasil wawancara boleh dipublikasikan secara umum. Selain itu, beberapa data didapat dari arsip perusahaan melalui website perusahaan. Pembuatan naskah berdasarkan pengumpulan data yang telah didapatkan dari hasil mewawancarai serta data arsip perusahaan dibuat dalam bentuk storyboard.

3) Studi Pustaka: Melakukan penelitian ilmiah dan mencari informasi dari kumpulan bahan yang menjadi rujukan, seperti jurnal untuk dijadikan landasan dasar dalam penyelesaian proyek. Studi Pustaka dilakukan untuk menjadi perbandingan serta menjadi bahan untuk melengkapi keterkaitan tentang multimedia. Langkah proses dan Teknik merekam baik dan sesuai.

\section{B. Metode Perancangan}

Proses mengumpulkan bahan dilakukan tanya jawab Bersama pihak instansi, serta akan disepakati bahwa hasil wawancara boleh dipublikasikan secara umum. Selain itu beberapa data didapat dari arsip perusahaan melalui website perusahaan. Penentuan ide, konsep dan pembuatan naskah berdasarkan pengumpulan data-data yang telah didapatkan dari hasil melakukan wawancara dan kepemilikan data arsip instansi dibuat dalam bentuk storyboard agar memudahkan penulis dalam merancang tampilan visual dan informasi yang akan disampaikan.

TABEL I

IDE DAN KONSEP VIDEO COMPANY PROFILE

\begin{tabular}{|l|l|}
\hline Ide & $\begin{array}{l}\text { Perancangan Video Company Profile BP2RD Kota } \\
\text { Batam }\end{array}$ \\
\hline Konsep & $\begin{array}{l}\text { Penyampaian informasi umum BP2RD Kota } \\
\text { Batam }\end{array}$ \\
\hline
\end{tabular}

1) Naskah : merupakan gambaran ide cerita secara keseluruhan pada pembuatan video company profile BPPRD Kota Batam. Berikut berdasarkan tabel 3.2 adalah naskah yang ditulis berdasarkan hasil diskusi dengan pihak perusahaan seperti ditunjukkan pada Tabel II.

2) Storyboard: Pada video company profile BPPRD Kota Batam akan menyampaikan informasi sejarah, profil, visi dan misi, dan hasil realisasi BP2RD Kota Batam. Storyboard menyajikan informasi dalam bentuk tabel yang berisikan scene, objek perekaman sebagai referensi visual, shot list, timing, dan audio yang digunakan seperti ditunjukkan pada Tabel II. 
TABEL II

NASKAH VIDEO COMPANY PROFILE

FADE IN :
EXT. Batam - Siang Hari
CAST
LS, Scene footage menampakkan Kota Batam secara
umum, Welcome To Batam.
umum, Welcome To Batam.

FADE IN :

CUT TO

EXT. BATAM - Siang Hari

CAST

LS, Scene footage menampakkan Kota Batam secara umum, , Bundaran Tuah Madani.

FADE IN :

EXT. BATAM - Siang Hari

CAST

LS, Scene footage menampakkan Kota Batam secara umum, Jembatan 1 Barelang.

FADE IN :

INT. BATAM - Siang Hari

CAST

MS, Penampakan dinding yang bertuliskan BPPRD

Kota Batam

FADE IN :

INT. BATAM - Siang Hari

CAST

MS, Penampakan pelayanan yang dilakukan di mall pelayanan public Kota Batam

FADE IN :

INT. BATAM - Siang Hari

CAST

MS, Penampakan pelayanan yang dilakukan di BPPRD Kota Batam

FADE IN :

INT. BATAM - Siang Hari

CAST

MS, Penampakan ruang tunggu dan antrian di BPPRD Kota Batam

TABEL III

STORYBOARD

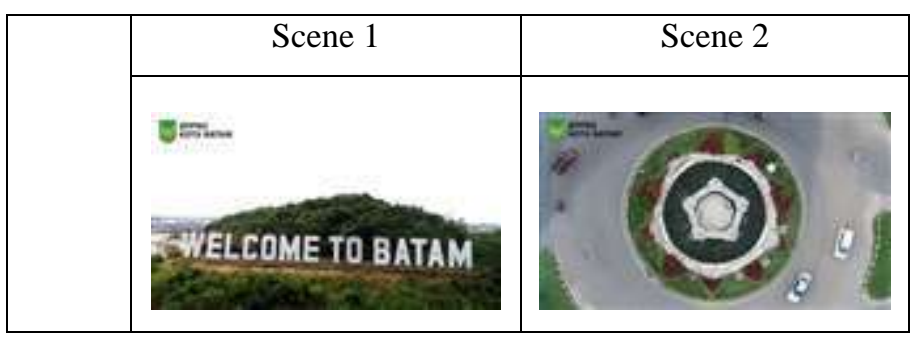




\begin{tabular}{|c|c|c|}
\hline $\begin{array}{c}\text { Shot - } \\
\text { list }\end{array}$ & Long shot & Long shot \\
\hline Tim- & $00.00-00.02$ & $00.02-00.05$ \\
ing & & Fx :- \\
\hline \multirow{3}{*}{ Audio } & Fx :- & Vo : - \\
\cline { 2 - 3 } & Lancang kuning.mp3 & Lancang kuning.mp3 \\
\hline
\end{tabular}

\begin{tabular}{|c|c|c|}
\hline \multirow{4}{*}{} & Scene 3 & Scene 4 \\
\cline { 2 - 3 } & Long shot & \\
\hline $\begin{array}{c}\text { Shot - } \\
\text { list }\end{array}$ & & Long shot \\
\hline Tim- & $00.05-00.07$ & $00.07-00.10$ \\
\hline \multirow{3}{*}{ Audio } & Fx : - & Fx : - \\
\cline { 2 - 3 } & Lancang kuning.mp3 & Lancang kuning.mp3 \\
\hline
\end{tabular}

\begin{tabular}{|c|c|c|}
\hline & Scene 5 & Scene 6 \\
\hline $\begin{array}{c}\text { Shot - } \\
\text { list }\end{array}$ & Long shot & Long shot \\
\hline Tim- & $00.10-00.14$ & $00.14-00.17$ \\
\hline ing & & Fx :- \\
\hline Audio & Vo : - & Vo : - \\
\hline & Lancang kuning.mp3 & Lancang kuning.mp3 \\
\hline
\end{tabular}

\begin{tabular}{|l|l|l|}
\hline Scene 7 & Scene 8 \\
\hline
\end{tabular}




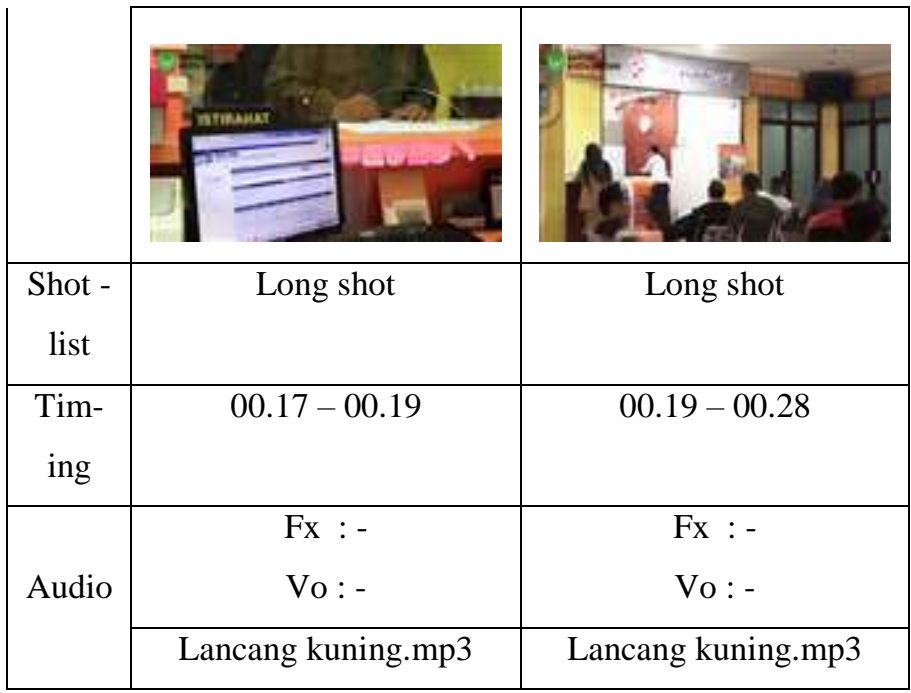

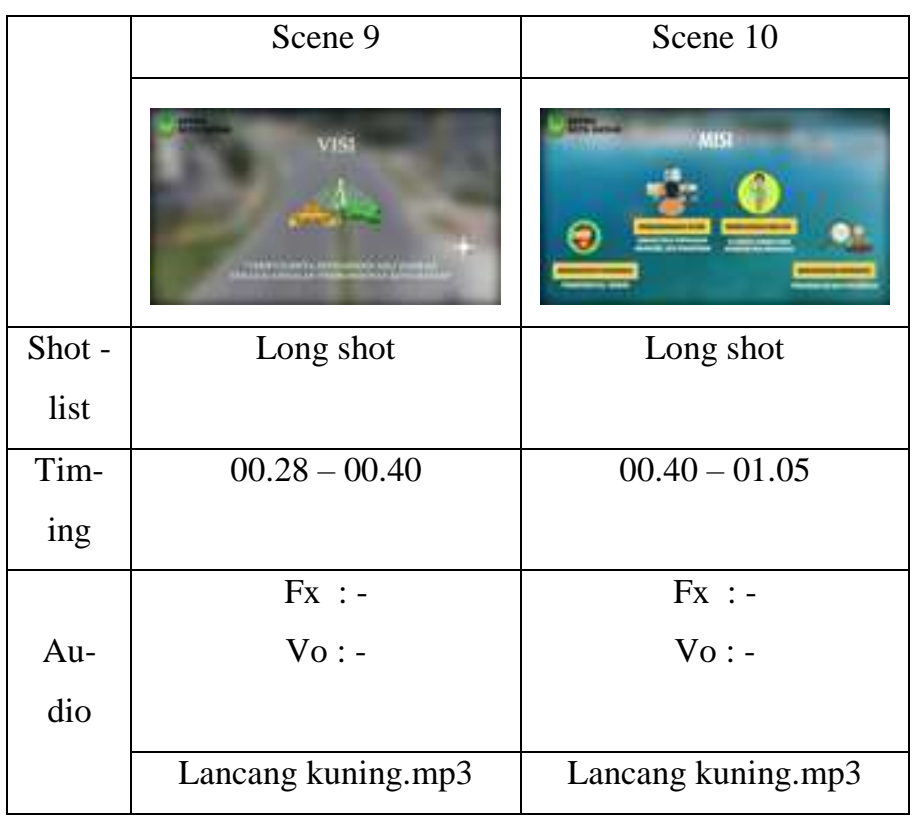

\section{Metode Analisis}

Pada penyajian data memakai metode analisis data kuantitatif dengan mengajukan pertanyaan kepada responden memakai kuesioner dengan menyebarkan kuesioner di goole form. Menurut Sugiyono dalam bukunya menyatakan penggunaan metode kuantitatif digunakan apabila ingin mengetahui pengaruh/treatment tertentu terhadap yang lain. Data didapat dari instrument yang berupa kuesioner, disebarkan kepada 30 orang responden, yang memuat 6 pertanyaan kejelasan isi video.

Responden penelitian dilakukan responden secara acak dengan latar belakang pekerjaan sebagai mahasiswa, pekerja swasta, wiraswasta, dan sebagainya. Dengan rentang usia 20 tahun sampai 50 tahun. Kualifikasi tersebut dipilih karena berkaitan dengan kategori masyarakat, staf dinas terkait yang melakukan kunjungan kerja, dan merupakan wajib pajak. Kuesioner yang dipakai berbentuk skala guttman. Pada kuesioner terdapat 2 skala respon yaitu ya dan tidak.

\section{Skala Guttman}

merupakan skala kumulatif. Skala Guttman ingin mengukur satu dimensi saja dari suatu variabel yang multidimensi. Untuk menganalisis jawaban yang diperoleh, berdasarkan teori Guttman digunakan perhitungan distribusi frekuensi sebagai berikut :

$$
\text { Jumlah skor }(\%)=\frac{\text { Jumlah Skor }}{\mathrm{n}} \times 100 \%
$$


Jumlah indikasi yang ada pada bahasan sebanyak (n) skor tertinggi untuk setiap pertanyaan adalah 1, sedangkan skor terendah adalah 0 . Penentuan skoring pada kriteria objektif :

$$
\mathrm{I}=\frac{\mathrm{R}}{\mathrm{K}}
$$

Dimana :

I = Interval

$\mathrm{R}=$ Range (skor tertinggi - skor terendah)

$\mathrm{K}$ = Kategori (banyaknya kriteria yang disusun pada kriteria objektif suatu variabel dengan kategori yaitu baik dan buruk).

Gambaran hasil penelitian dengan wawancara di BP2RD Kota Batam. Analisis jawaban menggunakan metode skala Guttman.

Dengan menentukan skoring pada kriteria objektif :

Dimana:

$$
\mathrm{I}=\frac{\mathrm{R}}{\mathrm{K}}
$$

$\mathrm{R}=100 \%-0 \%=100 \%$

$\mathrm{K}=2$ (baik/buruk)

Maka:

$$
\mathrm{I}=\frac{100}{2}=50 \%
$$

Kriteria penilaian $=$ skor tertinggi - interval

$=100 \%-50 \%=50 \%$

Sehingga penentuan kriteria penilaian pada penerapan adalah sebagai berikut :

- Jumlah skor $>50 \%=$ Baik

- Jumlah skor $<50 \%=$ Buruk

Pernyataan dalam bentuk pilihan jawaban (ya/tidak) ini dibuat berdasarkan hasil wawancara dan ceklist yang dilakukan.

\section{HASIL DAN PEMBaHASAN}

Hasil pada penelitian yang telah dilakukan adalah video company profile BP2RD Kota Batam yang digunakan sebagai media pengenalan instansi

\section{A. Produksi}

Produksi merupakan tahapan penguraian proses eksekusi konsep serta ide cerita dengan disertai pengambilan gambar. Produksi ini dilakukan di dalam Gedung (indoor) Dinas Bersama Pemko Batam, BP2RD Kota Batam, Batam Centre.

\section{B. Pasca Produksi}

Pasca produksi merupakan tahapan akhir yang dilakukan setelah proses produksi dilakukan terhadap semua bahan video yang telah dipilih. Dalam pembuatan video company profile BP2RD, meliputi pengeditan, pemberian efek, kemudian percampuran video dan audio.

1) Proses Editing; Editing merupakan proses penyeleksian, proses susun dan menyatuhkan Kembali video yang telah dipotong menjadi sebuah video atau produk dari rangkaian scene. Dalam tahapan ini, $80 \%$ ialah seleksi (selecting), melengkapi, dan memasang (assembling) gambar-gambar dari kamera (shot) terbaik kedalam adegan-adegan (scene). Pengolahan data selanjutnya dilakukan dengan proses capturing, yaitu proses memindahkan video dari sumber media yakni kamera ke dalam hardisk atau komputer. Pada tahap pengeditan, penulis akan memakai aplikasi Adobe Premiere Pro cc 2015. Proses pengeditan dilakukan pada effect control panel. Merangkai setiap scene gambar sesuai dengan storyboard. Selanjutnya memasukkan efek Cross Dissolve untuk membuat tampilan awal pada scene pertama terlihat sebagai opening video. Pemberian suara narasi serta musik pendukung untuk video. Proses terakhir yang dilakukan adalah render dan export yaitu proses penggabungan dari semua file video menjadi file akhir atau output berupa video. 


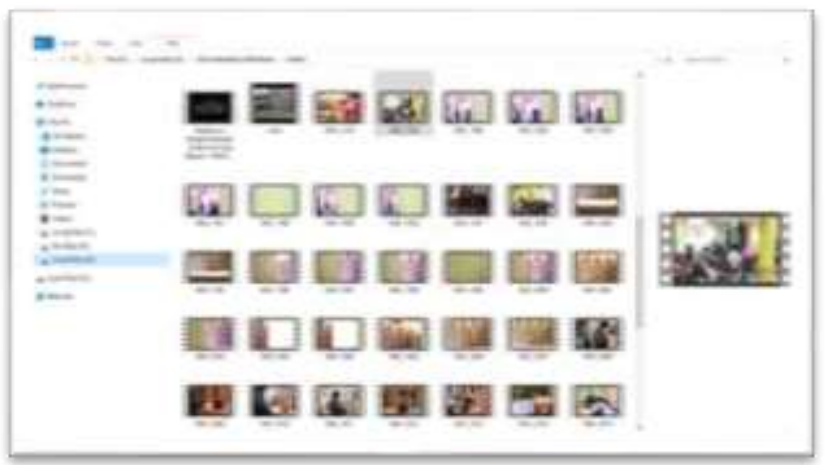

Gambar 1. Proses capturing video

Setelah melakukan pengambilan gambar dan juga video. Maka selanjutnya hasil rekaman dipindahkan ke laptop atau komputer yang akan digunakan untuk mengedit video. Setelah dipindahkan, video yang telah direkam dapat dipilah menjadi video yang akan digunakan atau video yang tidak digunakan.

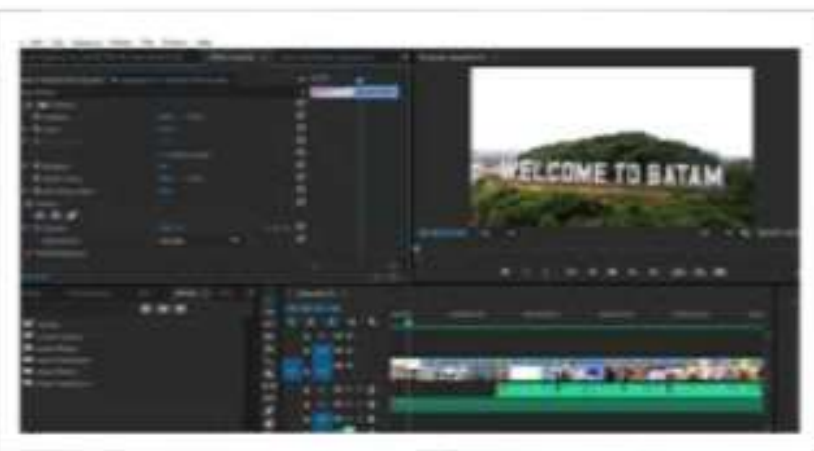

Gambar 2. Proses editing video menggunakan software adobe premiere pro.

Pastikan terlebih dahulu software adobe premiere pro sudah terinstall di laptop atau komputer. Video yang telah dipilih kemudian impor ke panel project adobe premiere pro. kemudian gabungkan semua video sesuai dengan scene per scene.

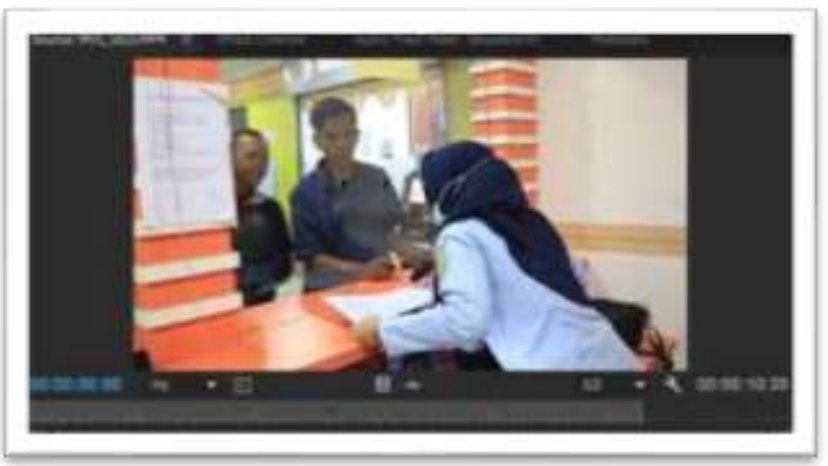

Gambar 3. Proses pemotongan video dilakukan secara manual pada setiap frame

Video yang sudah diimpor ke panel project adobe premiere pro diseret ke timeline. Klik video yang telah diseret kemudian potong bagian depan atau belakang video yang tidak perlu masuk di dalam scene. 


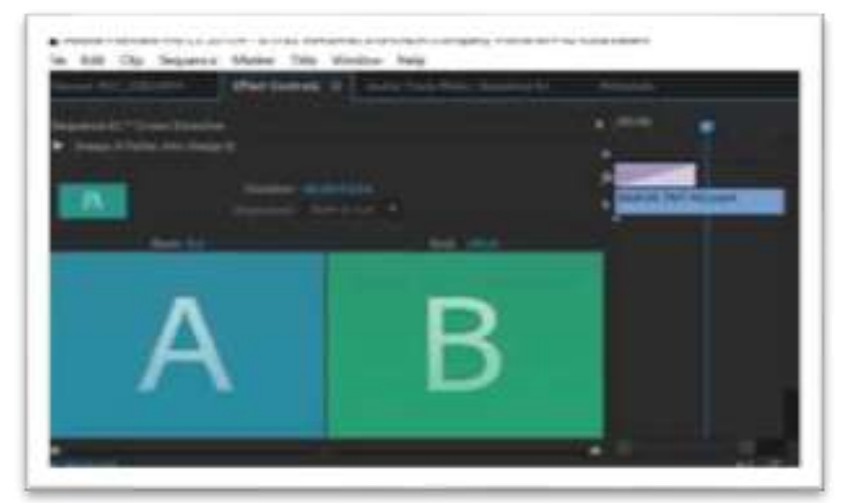

Gambar 4. Proses pemberian efek

Pilih video dengan mengkliknya, video akan menyorot video pada timeline. klik effects kemudian akan muncul video effects. Setelah itu daftar kategori efek video akan terbuka. sesuaikan efek yang ingin digunakan.

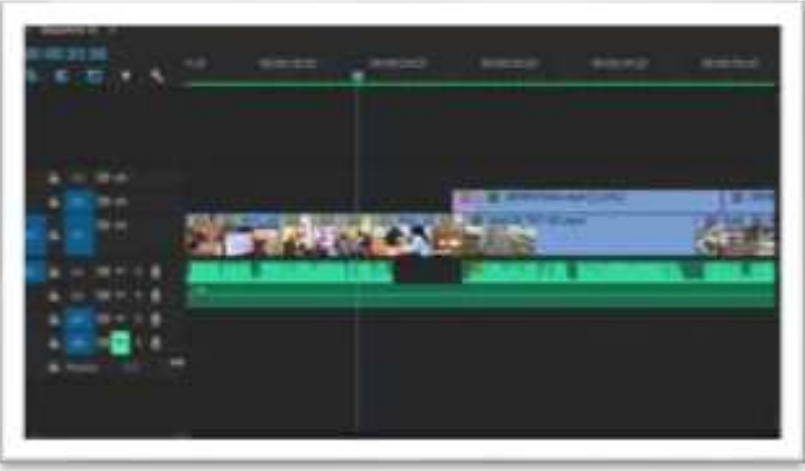

Gambar 5. Proses penambahan backsound dan dubbing suara.

Musik yang sudah diimpor ke panel project adobe premiere pro diseret ke timeline. Klik musik yang telah diseret kemudian potong bagian depan atau belakang musik yang tidak akan digunakan didalam scene.

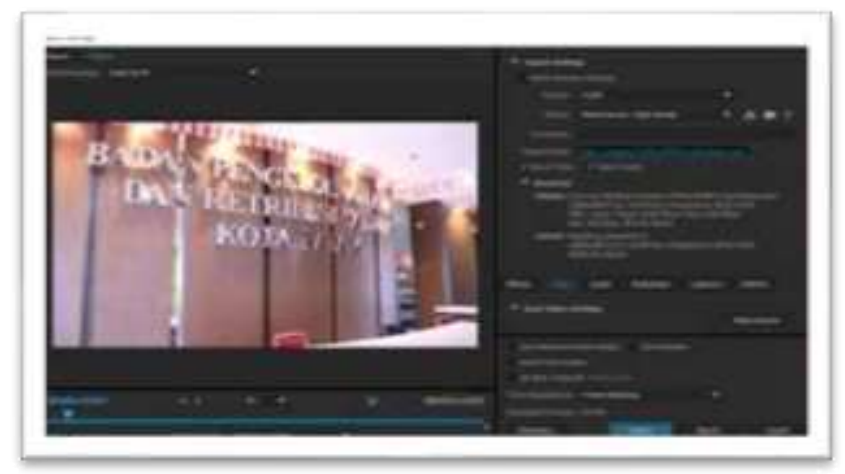

Gambar 6. Proses export video

Setelah video selesai di edit di adobe premiere pro maka pilih file kemudian export dan pilih media. Pilihlah format yang diinginkan, pada umumnya menggunakan format mp4 dan ukurannya. Simpanlah video dengan memberi nama video yang kita inginkan dan lokasi penyimpanannya, kemudian export. 
2) Distribusi; pendistribusian hasil dari perancangan video company profile yaitu untuk ditampilkan di Ruang Rapat BP2RD Kota Batam. Kunjungan kerja yang dilakukan di BP2RD Kota Batam baik yang dilakukan dari dalam kota maupun kunjungan kerja dari luar kota, dari dinas terkait ataupun dari unsur lain akan dibawa keruang rapat dan akan ditampilkan video company profile BP2RD Kota Batam.

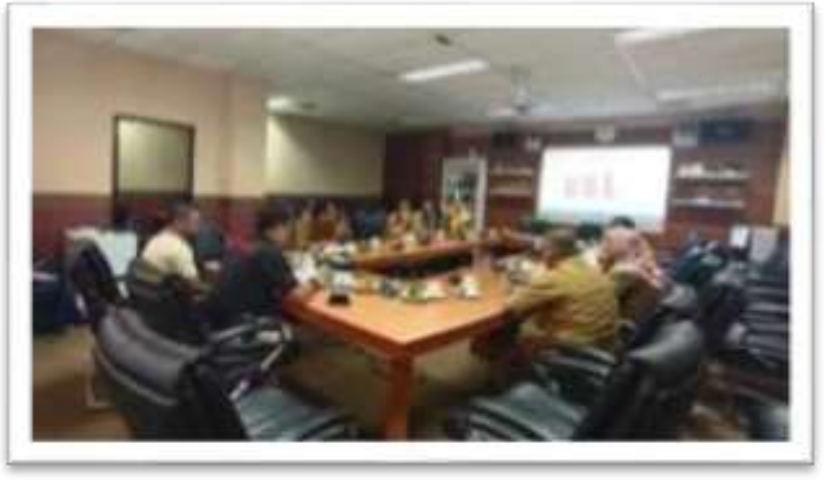

Gambar 7. Proses distribusi video pada ruang rapat

Setelah selesai video kemudian ditampilkan kepada Kabid PEvSI dan Kasi BPPRD. Untuk memberikan masukan dan koreksi terhadap video. Proses distribusi video dilakukan di ruang rapat BPPRD Kota Batam.

3) Hasil Pengujian; setelah pembuatan video, maka dilanjutkan dengan pengujian yang dilakukan dengan wawancara. Berikut adalah hasil wawancara dalam Tabel 3.

TABEL IV

TABEL HASIL WAWANCARA

\begin{tabular}{|c|c|c|c|}
\hline \multicolumn{4}{|c|}{ Hasil Wawancara } \\
\hline \multirow{2}{*}{ No } & \multirow{2}{*}{ Aspek } & \multicolumn{2}{|c|}{ Jumlah Respon } \\
\hline & & Ya & Tidak \\
\hline 1 & $\begin{array}{l}\text { Apakah Video yang } \\
\text { ditampilkan pada video } \\
\text { company profile BP2RD Kota } \\
\text { Batam telah memuat Sejarah } \\
\text { singkat, Visi dan Misi, Jenis } \\
\text { Pajak Daerah dan Program } \\
\text { Kerja BP2RD Kota Batam. }\end{array}$ & 26 & 4 \\
\hline 2 & $\begin{array}{l}\text { Apakah Penjelasan yang } \\
\text { ditampilkan pada video } \\
\text { company profile BP2RD Kota } \\
\text { Batam mengenai Sejarah } \\
\text { singkat, Visi dan Misi, Jenis } \\
\text { Pajak Daerah, Target Realisasi } \\
\text { Pajak Daerah dan Program } \\
\text { Kerja BP2RD Kota Batam telah } \\
\text { dijelaskan secara singkat } \\
\text { namun pendengar mendapatkan } \\
\text { informasi yang jelas. }\end{array}$ & 29 & 1 \\
\hline 3 & $\begin{array}{l}\text { Apakah Grafik Target dan } \\
\text { Realisasi Pajak Daerah yang } \\
\text { ditampilkan pada video } \\
\text { company profile menggunakan } \\
\text { data akurat dan sesuai. }\end{array}$ & 26 & 4 \\
\hline
\end{tabular}




\begin{tabular}{|c|c|c|c|}
\hline \multicolumn{4}{|c|}{ Hasil Wawancara } \\
\hline \multirow{2}{*}{ No } & \multirow{2}{*}{ Aspek } & \multicolumn{2}{|c|}{ Jumlah Respon } \\
\hline & & $\mathrm{Ya}$ & Tidak \\
\hline 4 & $\begin{array}{l}\text { Apakah Logo Pemerintah } \\
\text { Kota Batam ditampilkan di } \\
\text { dalam video company profile } \\
\text { BP2RD Kota Batam sebagai } \\
\text { pengenal instansi BP2RD } \\
\text { Kota Batam merupakan } \\
\text { bagian Pemerintah Kota } \\
\text { Batam. }\end{array}$ & 29 & 1 \\
\hline 5 & $\begin{array}{l}\text { Apakah Suara backsound } \\
\text { menggunakan musik melayu } \\
\text { sebagai ciri khas Kota Batam } \\
\text { yang merupakan Tanah } \\
\text { Melayu. Suara penjelasan } \\
\text { tentang Sejarah singkat, Visi } \\
\text { dan Misi, Jenis Pajak Daerah } \\
\text { dan Program Kerja BP2RD } \\
\text { Kota Batam melalui suara } \\
\text { dubbing narasi. }\end{array}$ & 27 & 3 \\
\hline 6 & $\begin{array}{l}\text { Apakah Video Company } \\
\text { Profile berdurasi } 5 \text { Menit } 4 \\
\text { Detik dan Pada outro } \\
\text { (penutup) video menampilkan } \\
\text { logo Pemerintah Kota Batam. }\end{array}$ & 28 & 2 \\
\hline
\end{tabular}

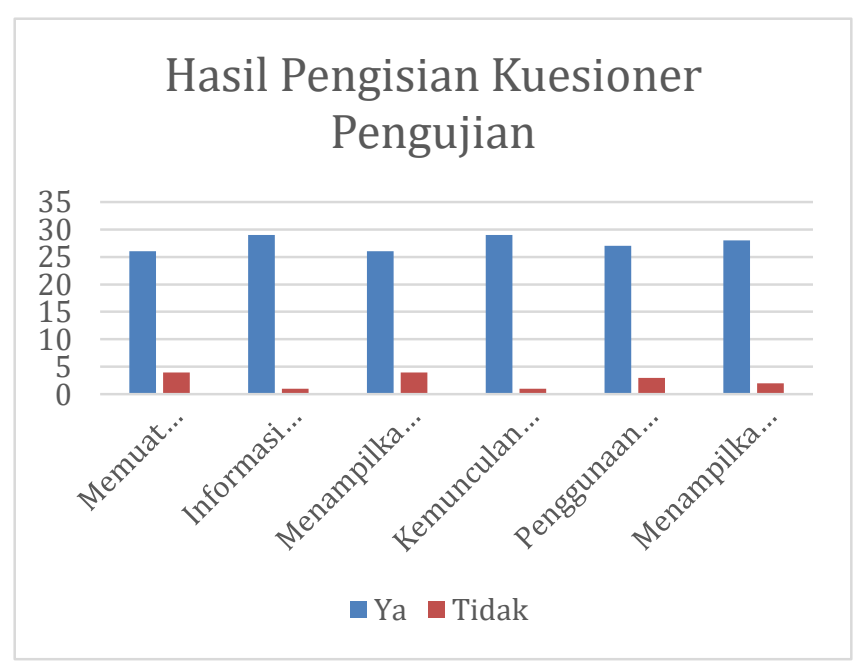

Gambar 8. Grafik pengisian kuesioner pengujian oleh 30 responden

Dari hasil grafik pengisian kuesioner di atas dapat dilihat bahwa responden pengujian rata rata memilih respon Ya. Setelah itu hasil dari pengisian kuesioner dihitung dengan rumus skala Guttman. Berikut adalah perhitungan skala Guttman pada table IV.

TABEL V

TABEL HASIL WAWANCARA

\section{Hasil Wawancara}




\begin{tabular}{|c|c|c|c|}
\hline \multirow{2}{*}{ No } & \multirow{2}{*}{ Aspek } & \multicolumn{2}{|c|}{ Jumlah Respon } \\
\hline & & Skor & $\%$ \\
\hline 1 & 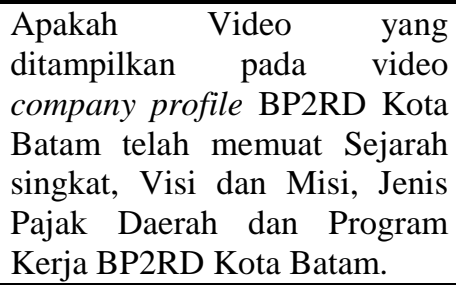 & 26 & $86,6 \%$ \\
\hline 2 & $\begin{array}{l}\text { Apakah Penjelasan } r \text { yang } \\
\text { ditampilkan pada video } \\
\text { company profile BP2RD Kota } \\
\text { Batam mengenai Sejarah } \\
\text { singkat, Visi dan Misi, Jenis } \\
\text { Pajak Daerah, Target Realisasi } \\
\text { Pajak Daerah dan Program } \\
\text { Kerja BP2RD Kota Batam telah } \\
\text { dijelaskan secara singkat } \\
\text { namun pendengar mendapatkan } \\
\text { informasi yang jelas. }\end{array}$ & 29 & $96,6 \%$ \\
\hline 3 & $\begin{array}{l}\text { Apakah Grafik Target dan } \\
\text { Realisasi Pajak Daerah yang } \\
\text { ditampilkan pada video } \\
\text { company profile menggunakan } \\
\text { data akurat dan sesuai. }\end{array}$ & 26 & $86,6 \%$ \\
\hline 4 & $\begin{array}{l}\text { Apakah Logo Pemerintah Kota } \\
\text { Batam ditampilkan di dalam } \\
\text { video company profile BP2RD } \\
\text { Kota Batam sebagai pengenal } \\
\text { instansi BP2RD Kota Batam } \\
\text { merupakan bagian Pemerintah } \\
\text { Kota Batam. }\end{array}$ & 29 & $96,6 \%$ \\
\hline 5 & $\begin{array}{l}\text { Apakah Suara backsound } \\
\text { menggunakan musik melayu } \\
\text { sebagai ciri khas Kota Batam } \\
\text { yang merupakan Tanah } \\
\text { Melayu. Suara penjelasan } \\
\text { tentang Sejarah singkat, Visi } \\
\text { dan Misi, Jenis Pajak Daerah } \\
\text { dan Program Kerja BP2RD } \\
\text { Kota Batam melalui suara } \\
\text { dubbing narasi. }\end{array}$ & 27 & $90 \%$ \\
\hline 6 & $\begin{array}{l}\text { Apakah Video } r \text { Company } \\
\text { Profile berdurasi } 5 \text { Menit } 4 \\
\text { Detik dan Pada outro (penutup) } \\
\text { video menampilkan logo } \\
\text { Pemerintah Kota Batam. }\end{array}$ & 28 & $96,6 \%$ \\
\hline & Rata - rata Persentase & & $92,1 \%$ \\
\hline
\end{tabular}




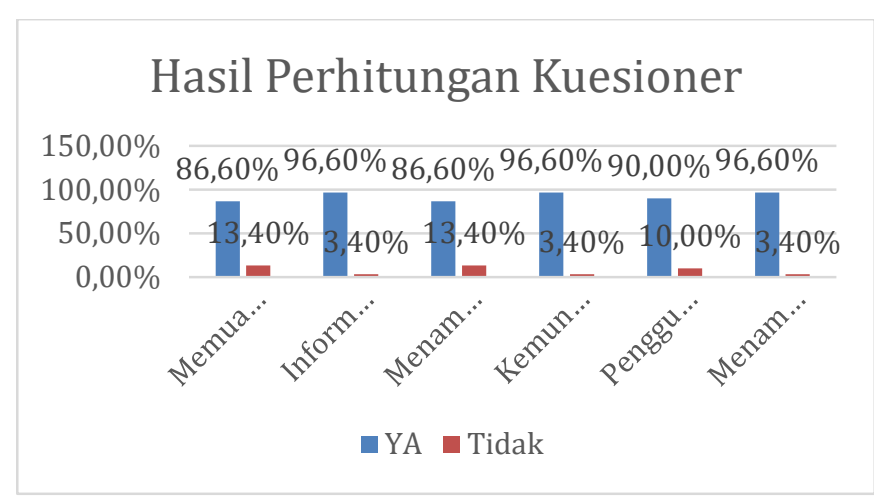

Gambar 9. Grafik Hasil Persentase Kuesioner

Berdasarkan rata rata persentase nilai pengujian mendapatkan hasil 92,1\% yang masuk ke dalam kategori baik. sehingga dapat disimpulkan bahwa video company profile BP2RD Kota Batam bisa menyampaikan informasi Instansi dengan jelas.

\section{KESIMPULAN}

Kesimpulan yang didapat dari hasil penelitian ini adalah video company profile BP2RD Kota Batam yang dikemas dalam format .mp4 berdurasi 5 menit 4 detik merupakan video tentang pengenalan instansi yang menyajikan informasi mengenai Sejarah singkat, Visi dan Misi, Jenis Pajak Daerah dan Program Kerja BP2RD Kota Batam. Setelah itu, berdasarkan hasil dari analisis pengujian dengan mendapatkan rata-rata persentase nilai secara berurut 92,5\%, dimana nilai persentase tersebut masuk kedalam kategori skala respon baik. Hal tersebut menunjukkan bahwa video company profile BP2RD Kota Batam bisa menyampaikan informasi instansi dengan jelas. Lalu, berdasarkan pengujian yang telah dilakukan, video company profile BP2RD Kota Batam layak untuk digunakan sebagai media pengenalan instansi.

\section{Daftar Pustaka}

[1] A. Kausar, Y. F. Sutiawan, and V. Rosalina, "Perancangan Video Company Profile Kota Serang Dengan Teknik Editing Menggunakan Adobe Premier Pro Cs 5,” J. PROSISKO, vol. 2, no. 1, 2015.

[2] F. S. Kusuma, "Perancangan Company Profile Berbasis Video Sebagai Media Promosi Smk Muhammadiyah 1 Kepanjen,” pp. 1-4, 2013.

[3] M. Maimunah, L. Sunarya, and N. Larasati, "Media Company Profile Sebagai Sarana Penunjang Informasi Dan Promosi," CCIT J., vol. 5, no. 3, pp. 281-301, 2012, doi: 10.33050/ccit.v5i3.155.

[4] L. Sunarya and S. Sn, "Diktat Mata Kuliah Desain Karakter dan Modeling." Maimunah, 2012.

[5] R. Kriyantono, Public relations writing: Teknik produksi media public relations dan publisitas korporat. Kencana, 2008.

[6] R. Godfrey, "New Wine in Old Bottle: Multimedia Design Methodology," in ASCILITE, 1995, vol. 95.

[7] I. Binanto, Multimedia digital-dasar teori dan pengembangannya. Penerbit Andi, 2010.

[8] F. Y. Satriyani, "PENGEMBANGAN BAHAN AJAR MULTIMEDIA BERBASIS MULTIPLE INTELLIGENCES DAN NILAI-NILAI PANCASILA,” Pedagog. J. Pendidik., vol. 5, no. 2, pp. 155-171, 2018.

[9] D. M. Gayeski, "Video-based instruction," Handb. Hum. Perform. Technol. A Compr. Guid. Anal. solving Perform. Probl. Organ. San Fr. Jossey-Bass, 1992.

[10] J. Jeffcoate, Multimedia in practice: technology and applications. Prentice-Hall, Inc., 1995. 